\title{
Tomasz Stryjewski
}

\section{ANALIZA ZACHOWANIA PRZEDSIĘBIORSTWA WOBEC RYZYKA RYNKOWEGO}

\begin{abstract}
Z a r y s t r e ś c i. Ryzyko rynkowe jest nieodłącznym zjawiskiem w prowadzeniu działalności gospodarczej. Wraz ze wzrostem ryzyka niektóre przedsiębiorstwa reagują racjonalnie, starając się ograniczyć jego wpływ na swoją działalność (działanie defensywne), inne natomiast upatruja szansę na wzrost udziału w rynku i podniesienie rentowności w momentach turbulencji (działanie agresywne). Wówczas mogą one zrealizować dodatkową premię wynikającą z działalności na trudnym rynku. $\mathrm{W}$ artykule podjęto próbę analizy reakcji przedsiębiorstwa na zmiany ryzyka rynkowego za pomocą modelu GARCH-M.
\end{abstract}

S ł o w a k 1 u c z o w e: analiza ryzyka, model GARCH-M, przedsiębiorstwo.

K 1 a s y fi k a c j a J E L: C1, C22, C58, G32.

\section{WSTĘP}

Ryzyko jest ważnym elementem działalności przedsiębiorstwa. Wyróżniamy wiele rodzajów ryzyka, a ich podział może zależeć od formy prowadzenia działalności gospodarczej. W pracy (Banaszkiewicz, Bejm i inni, 2003, s. 69) autorzy wyróżnili następujące rodzaje ryzyka:

1. Ryzyka zewnętrzne - ryzyka związane ze środowiskiem, w którym funkcjonuje organizacja;

2. Ryzyka wewnętrzne - ryzyka wynikające ze sposobu funkcjonowania organizacji, w tym:

a) ryzyka związane $z$ procesami działalności, w tym:

- ryzyka operacyjne,

- ryzyka związane z charakterem struktury organizacyjnej,

- ryzyka związane z przetwarzaniem informacji, technologią informatyczną, zarządzaniem wiedzą,

\footnotetext{
* Adres do korespondencji: Tomasz Stryjewski, Wyższa Szkoła Informatyki i Ekonomii TWP, ul. Barczewskiego 11, 10-061 Olsztyn, e-mail: tomasz.stryjewski@wsiie.olsztyn.pl. 
- ryzyka związane z działalnością niezgodną z prawem oraz wewnętrznymi regulaminami,

- ryzyka związane $z$ finansami,

b) ryzyka związane z pozyskiwaniem i analizą informacji niezbędnej do zarządzania, w tym:

- ryzyka informacji operacyjnych,

- ryzyka informacji finansowej,

- ryzyka informacji strategicznej.

Jak można zauważyć powyższy podział dotyczy głównie ryzyk związanych z procesami toczącymi się wewnątrz organizacji. Procesy zewnętrzne opisane są w sposób zagregowany. Wynika to w dużej mierze $\mathrm{z}$ faktu, iż przedsiębiorstwo nie jest w stanie bezpośrednio nimi zarządzać. Często podyktowane to jest słabą kwantyfikacją i problemami z pomiarem ryzykownych zjawisk w otoczeniu.

Niezależnie od trudności w identyfikacji i pomiarze ryzyk zewnętrznych to przedsiębiorstwa uwzględniają je w swojej strategii w postaci szans lub zagrożeń. W zależności od zakwalifikowania ryzyka jako szansy bądź zagrożenia firmy podejmują różne działania. $Z$ jednej strony przedsiębiorstwo broni się przed wzrostem ryzyka, a z drugiej strony może starać się wykorzystać premię, która w warunkach zwiększonych turbulencji może wykazywać ponadprzeciętne wartości. Jednym $z$ istotnych rodzajów ryzyka jest ryzyko rynkowe rozumiane jako amplituda wahań popytu efektywnego na produkty przedsiębiorstwa. Celem artykułu jest próba określenia zachowania przedsiębiorstwa wobec zmiany ryzyka rynkowego za pomocą modelu GARCH-M.

\section{PRZEDSIĘBIORSTWO}

Peter Drucker wyróżnił co najmniej 2 rodzaje przedsiębiorstw, o odmiennej specyfice prowadzenia działalności gospodarczej. Są to przedsiębiorstwa o produkcji jednostkowej oraz przedsiębiorstwa o produkcji ciagłej (Drucker, 2005, s. 159). Charakterystyka obydwu rodzajów prowadzonej działalności powoduje, że podział taki jest wciąż zasadny.

Przedsiębiorstwo o produkcji jednostkowej wytwarza produkty na konkretne zamówienie (na kontrakt). Produkowane wyroby są zatem niepowtarzalne, unikatowe. Powtarzalne są jedynie czynności w procesach wytwórczych. Głównym elementem obniżania kosztów jest krzywa doświadczenia, która nie stanowi jednak bariery wejścia na rynek (Porter, 2006, s. 33). Przykładem takiego przedsiębiorstwa jest firma budowlana.

Głównym zdaniem kadry kierowniczej jest pozyskanie kontraktu (zlecenia) oraz kontrola jego wykonania. W przedsiębiorstwie o tym charakterze produkcji najważniejszym elementem działalności jest produkcja, gdyż sprzedaż jest tylko jej pochodną.

Przedsiębiorstwo o produkcji ciagłej wytwarza jednolity produkt lub różne produkty ze standardowych części. Głównym elementem obniżania kosztów jest ekonomika skali, która jest jednym z elementów tworzenia barier wejścia. 
Kalkulacja i analiza produktu oparta jest na koszcie jednostkowym, a nie na budżetach jak w przypadku zarządzania projektem.

Głównym zadaniem kadry kierowniczej jest kreacja potrzeb, rozwój dystrybucji i lojalności klienta. Najważniejszym elementem jest sprzedaż, a produkcja w tym przypadku jest jej pochodna.

Wyznaczenie kluczowych elementów, na których oparta jest działalność przedsiębiorstw o różnych modelach biznesowych ma podstawowe znaczenie dla dalszej analizy, gdyż określanie ryzyka rynkowego może następować tylko poprzez tę zmienną. Badanie będzie polegało na analizie wahań wartości kosztu produkcji w przedsiębiorstwie budowlanym oraz wpływu tej zmienności w relacji zwrotnej.

W klasycznym ujęciu $\mathrm{w}$ mikroekonomii, produkcja jest uzależniona od czynników produkcji, jakimi są: ziemia, kapitał rzeczowy i praca. W przedsiębiorstwie, oprócz przedsiębiorstw stricte rolnych, ziemia stanowi marginalny czynnik produkcji. Pojęcie produkcji nierozerwalnie złączone jest z pojęciem technologii. Dzieje się tak, gdyż przedsiębiorstwo poszukuje optymalnych nakładów czynników produkcji tzn. pracy i kapitału rzeczowego poprzez porównanie swojego ograniczenia budżetowego oraz technologii. Możliwości produkcyjne przedsiębiorstwa przedstawia funkcja produkcji, np. funkcja produkcji Cobba-Douglasa (por. Żółtowska, 1997, s. 23; Gruszczyński, Podgórska, 1996, s. 148; Samuelson, Marks, 1998, s. 249), czyli zależność między wielkością poniesionych nakładów na produkcję dóbr a osiaggniętymi wynikami:

$$
Q=A x_{1}^{a} x_{2}^{b},
$$

gdzie: $Q$ oznacza wolumen produkcji, $x_{1}$ i $x_{2}$ oznaczają nakłady czynników produkcji oraz $A, a, b$ oznaczaja parametry funkcji produkcji.

Funkcja produkcji wskazuje technicznie możliwą wielkość produkcji. Wykres tej funkcji jest zdeterminowany prawem malejących przychodów, co oznacza, że jeżeli nakłady jednego czynnika produkcji są stałe, to zwiększanie nakładów innego czynnika produkcji powoduje coraz mniejsze przyrosty produkcji. $\mathrm{W}$ równaniu (1) wolumen produkcji jest opisany za pomocą dwóch czynników np. kapitał rzeczowy i pracę oraz przez różne ich kombinacje zależne od wartości parametrów funkcji.

Funkcja Cobba-Douglasa ma kilka własności (por. Samuelson, Marks, 1998, s. 251):

1. Krańcowy produkt pracy zależy zarówno od nakładu pracy, jak również od nakładu kapitału rzeczowego. Maleje on w miarę zwiększania nakładów pracy przy niezmienionych nakładach kapitału - prawo malejącej krańcowej produkcyjności. Krańcowy produkt pracy rośnie wraz ze zwiększeniem komplementarnego czynnika produkcji, jakim jest kapitał rzeczowy. Oznacza, to że funkcja produkcji w krótkim okresie jest zależna od czynnika zmiennego - pracy i podlega prawu jego malejącej krańcowej produkcyjności. W długim okresie wraz z możliwością zmiany technologii i zmiany 
nakładu kapitału rzeczowego można uzyskać wzrost produkcyjności poniesionych nakładów.

2. Charakter przychodów ze skali produkcji zależy od sumy parametrów $a$ i $b$, które należą do przedziału $[0,1]$. Stałe przychody ze skali produkcji występują, gdy suma parametrów będący wykładnikami potęg jest równa jedności, korzyści ze skali produkcji występują wówczas, gdy suma wykładników potęg jest większa od jedności, a niekorzyści skali występują gdy suma ta jest mniejsza od jedności.

Funkcja produkcji Cobba-Douglasa (1) nie jest jedyną formą przedstawienia zależności pomiędzy wolumenem wytworzenia a poniesionymi nakładami, jest jednak dogodną formą przykładowego przedstawienia tych zależności. Ze względu na jej dużą popularność doczekała się ona wielu przekształceń i modyfikacji. Bardziej ogólnym narzędziem opisującym relację pomiędzy nakładami a produkcją jest funkcja CES w postaci (por. Gruszczyński, Podgórska, 1996, s. 157):

$$
Q=A\left(\delta X_{1}^{-p}+(1-\delta) X_{2}^{-p}\right)^{-\frac{v}{p}}
$$

gdzie: $A$ - parametr przychodu charakteryzujący wydajność techniki, $\delta$ - parametr podziału charakteryzujący intensywność czynnika $X_{I}$ w technice produkcji, $(1-\delta)$ - parametr charakteryzujący intensywność czynnika $X_{2} \mathrm{w}$ technice produkcji, $v$ - parametr skali, wyznacza stopień jednorodności produkcji, $p-$ parametr substytucji taki, że elastyczność substytucji wynosi $\sigma=\frac{1}{1+p}$.

Zarówno funkcja typu Cobba-Douglasa, jak również funkcja CES charakteryzują się stałą elastycznością substytucji. Rezygnacja z tego założenia prowadzi do budowy funkcji produkcji typu VES, które są rozwinięciem funkcji CobbaDouglasa. Przykładem takiego podejścia jest funkcja translogarytmiczna w postaci (por. Gruszczyński, Podgórska, 1996, s. 158; Żółtowska, 1997, s. 39):

$$
Q=A X_{1}^{a} X_{2}^{b} e^{\lambda \ln X_{2} \ln X_{1}+\gamma_{1}\left(\ln X_{1}\right)^{2}+\gamma_{2}\left(\ln X_{2}\right)^{2}},
$$

gdzie: $X_{1}, X_{2}$ - oznaczają czynniki produkcji, $a, b, \lambda, \gamma_{1}, \gamma_{2}$ - oznaczają parametry równania.

Forma i zakres pracy nie pozwala na prezentację wszystkich znanych postaci funkcji produkcji, jednakże powyższy opis stanowi dobry punkt wyjścia do określenia postaci funkcji opisującej produkcję w badanym przedsiębiorstwie budowlanym.

\section{MODEL GARCH-M}

Model GARCH (Generalized Autoregressive Conditional Heteroscedasticity Model) opisuje wariancję warunkową składnika resztowego, pozostałego z modelu dla warunkowej wartości oczekiwanej. Model GARCH (Bollerslev, 1986, s. 307-327) jest uogólnieniem wcześniejszego modelu ARCH (Engle, 
1982, s. 987-1007) a relacja pomiędzy nimi jest wzorowana na relacji pomiędzy modelami AR i ARMA dla opisu stacjonarnych szeregów czasowych.

Model GARCH(p, q) definiuje się w postaci 2 równan:

1. Równania dla warunkowej wartości oczekiwanej

$$
y_{t}=\sum_{j=0}^{n} a_{j} x_{j t}+\sum_{k=1}^{m} b_{k} y_{t-k}+e_{t},
$$

2. Równania dla warunkowej wariancji reszt, o rozkładzie $N\left(0, h_{t}\right)$

$$
h_{t}=\alpha_{0}+\sum_{i=1}^{p} \alpha_{i} e_{t-i}^{2}+\sum_{i=1}^{q} \beta_{i} h_{t-i},
$$

gdzie: $y_{t}$ - oznacza zmienną endogeniczna, $x_{j t}$ - oznacza zmienne egzogeniczne, $e_{t}$ - proces resztowy, oraz $q \geq 0, p>0, \alpha_{0}>0, \alpha_{i} \geq 0, \beta_{i} \geq 0$.

Warunek dodatniości parametru $\alpha_{0}$ oraz nieujemności pozostałych parametrów modelu GARCH(p, q) powoduje gwarancję dodatniej prognozy warunkowej wariancji.

Jeżeli $q=0$ to proces $\operatorname{GARCH}(\mathrm{p}, \mathrm{q})$ redukuje się do procesu ARCH(p). Można wykazać, że testowanie efektów ARCH i GARCH jest ekwiwalentne, a zatem stosowane testy statystyczne pozwalają na wskazanie efektu zmiennej wariancji, bez możliwości rozróżnienia, czy jest to ARCH czy GARCH. Najczęściej model GARCH stosuje się, gdy liczba opóźnień w modelu ARCH jest zbyt duża lub gdy kryteria informacyjne na etapie wyboru modelu wskazują na jego przewagę (Osińska, 2006, s. 85).

W klasycznych modelach (niefinansowych szeregów czasowych) występowanie efektu ARCH w resztach jest uznawane jako błąd specyfikacji modelu, uniemożliwiający zastosowanie niektórych metod estymacji, np. KMNK. Jednak czasami występowanie zmiennej w czasie warunkowej wariancji może być podyktowane nie tylko błędem specyfikacji modelu ale również własnościami badanych procesów. Jeżeli uznamy efekt ARCH za własność procesu ${ }^{1}$, odpowiadającą kształtowaniu się ryzyka, to wówczas można włączyć tę informację do modelu.

Model GARCH-in-mean (GARCH-M) pozwala na określenie wpływu warunkowej zmienności (ryzyka) modelowanej równaniem 5 na kształtowanie się procesu podstawowego opisywanego równaniem 4. Analiza taka odbywa się poprzez podstawienie teoretycznej warunkowej wariancji (obliczonej w równaniu 5) jako zmiennej egzogenicznej w równaniu 4.

Model GARCH-M ma postać (Engle, Lilien, Robins, 1987, s. 391-407):

$$
y_{t}=\sum_{j=0}^{k} \alpha_{j} x_{j t}+\delta \sqrt{h_{t}}+\varepsilon_{t},
$$

\footnotetext{
${ }^{1}$ Własność ta musi być ekonomicznie uzasadniona.
} 
gdzie: $y_{t}$ - oznacza zmienną endogeniczna, $x_{j t}$ - oznacza zmienne egzogeniczne, $h_{t}$ - proces $\operatorname{GARCH}(\mathrm{p}, \mathrm{q})$ dany równaniem 5 .

W klasycznej analizie dla procesów finansowych ocena parametru $\delta$ powinna być dodatnia i istotna statystycznie (Engle, Lilien, Robins, 1987, s. 391-407; Osińska, 2006, s. 89). Modele GARCH-M są najczęściej wykorzystywane $\mathrm{w}$ analizie finansowej przy modelowaniu stóp zwrotu i związanej z nimi premii za ryzyko, czyli wzrostu stopy zwrotu wraz ze wzrostem jej wariancji. Dodatniość parametru $\delta$ zapewnia relację opisującą dodatni wpływ wzrostu ryzyka na wzrost premii za nie.

$\mathrm{W}$ proponowanej w niniejszym artykule analizie, parametr $\delta$ powinien być statystycznie istotny ale może przyjmować wartości zarówno dodatnie jak również ujemne. Analiza ta będzie opierać się na modelowaniu procesu produkcji, bądź sprzedaż ${ }^{2} \mathrm{w}$ przedsiębiorstwie oraz reakcji na zmiany ryzyka rynkowego modelowanego za pomocą warunkowej wariancji tego procesu.

Jeżeli ocena parametru $\delta$ przyjmie w analizie wartość dodatnią oznaczać to będzie, że zachowanie przedsiębiorstwa ma charakter agresywny. Wówczas firma tak jak w przypadku modelowania stóp zwrotu realizuje premię za ryzyko działania i rozwijania produkcji, bądź sprzedaży w warunkach większych turbulencji rynkowych. Ujemne wartości oceny parametru $\delta$ oznaczać będą zachowanie defensywne przedsiębiorstwa, co najczęściej oznacza zmniejszenie aktywności i koncentrację na głównych (istniejących) kontraktach bądź rynkach.

\section{ANALIZA EMPIRYCZNA}

Analizy dokonano dla przedsiębiorstwa budowlanego na podstawie równania opisującego kształtowanie się procesu produkcji wyspecyfikowanego w oparciu o modelowanie zgodne (Talaga, Zieliński, 1986, s. 174) dla próby od stycznia 2001 r. do czerwca 2008 r. (90 obserwacji). Analiza różnych funkcji produkcji oraz sposobu funkcjonowania badanego przedsiębiorstwa pozwoliła na specyfikację przyczynowo-skutkową hipotezy modelowej dla dalszych rozważań. Ponieważ przedsiębiorstwo działa głównie poprzez podwykonawców oraz w systemie pracy kontraktowej, do opisu procesu produkcji zastosowano model pełny w postaci:

$$
\begin{aligned}
& A(u) \ln \left(\text { PROD }_{t}\right)=\alpha_{0}+B(u) \ln \left(W P_{t}\right) \\
& +C(u) \ln \left(F I Z_{t}\right)+D(u) \text { PRZET }_{t}+\eta_{t},
\end{aligned}
$$

gdzie: $P R O D_{t}$ - wartość produkcji w koszcie wytworzenia w okresie t, $W P_{t}-$ wydajność pracy pracowników fizycznych liczona od wartości produkcji przez nich wytworzoną w okresie t, $F I Z_{t}$ - liczba pracowników fizycznych w okresie t, PRZET $_{t}$ - udział wygranych przetargów w ogólnej liczbie przygotowanych (w tym prywatnych i publicznych), $\eta_{t}$ - składnik resztowy, $A(u), B(u), C(u)$,

\footnotetext{
${ }^{2} \mathrm{~W}$ zależności od rodzaju przedsiębiorstwa, co zostało opisane na początku artykułu.
} 
$D(u)$ - są autoregresyjnymi operatorami, dla których wszystkie pierwiastki równań charakterystycznych są co do modułu większe od jedności, $u$-operator przesunięcia wstecz. Zakłada się przy tym, że wszystkie procesy w modelu 7 są stacjonarne.

Jak się wydaje, zastosowane zmienne w modelu 7 mają swoje uzasadnienie w obserwacji badanego podmiotu. Firma ta bowiem wykonuje własnymi siłami głównie stany surowe obiektów. Wielkość i wydajność wkładu własnego ma zatem istotny wpływ na łączną wartość zrealizowanej produkcji. Jednakże nakładanie się poszczególnych faz różnych kontraktów powoduje, że uwzględnienie w modelu zespołowej wydajności pracy liczonej jako iloraz wartości produkcji wytworzonej $\mathrm{w}$ siłach własnych $\mathrm{w}$ stosunku do liczby zatrudnionych w przeliczeniu na pełne etaty ma swoje ekonomiczne i statystyczne uzasadnienie (współczynnik korelacji dla logarytmów procesów stacjonarnych wynosi 0,4517). Innym ważnym elementem zaproponowanego modelu opisującego kształtowania się wartości produkcji w czasie jest współczynnik skuteczności pozyskiwania kontraktów przez przedsiębiorstwo. Współczynnik ten informuje o sile konkurencyjności ( $w$ tym negocjacyjnej) przedsiębiorstwa na rynku. Umiejętność pozyskiwania kontraktów jest główną ekonomiczną przyczyną kształtowania się wartości produkcji w przedsiębiorstwie budowlanym, natomiast pozostałe zmienne równania 7 informuja jedynie o potencjale wytwórczym, potrzebnym do realizacji kontraktu. Przyjęta strategia powoduje, że oprócz wskazanych $\mathrm{w}$ równaniu 7 czynników wpływających na wartość produkcji, przedsiębiorstwo musi zapewnić ponadto odpowiednią płynność do obsługi zobowiązań wobec dostawców i podwykonawców. Jednakże jest to tylko potencjalna zmienna wynikająca ze zdolności kredytowej przedsiębiorstwa, nie została więc uznana jako potencjał wytwórczy i nie włączona do hipotezy modelowej.

Równanie 7 zostało oszacowane dla procesów stacjonarnych, a więc reszt odpowiednich $^{3}$ modeli trendowo-sezonowych. Tabela 1 przedstawia zredukowane jedynie do statystycznie istotnych ocen parametrów oszacowanie równania opisującego kształtowanie się procesu produkcji w badanym przedsiębiorstwie (Stryjewski, 2010, s. 21-24).

$\mathrm{Z}$ tabeli 1, przedstawiającej oszacowane i sprowadzone jedynie do statystycznie istotnych ocen parametrów równanie opisujące kształtowanie się procesu produkcji w badanym przedsiębiorstwie wynika, że uzyskano wysokie dopasowanie do procesu rzeczywistego na poziomie ok. 95\%. Zaprezentowana poniżej funkcja autokorelacji cząstkowej (PACF) wskazuje na brak autokorelacji reszt.

Jak wynika $\mathrm{z}$ modelu zaprezentowanego $\mathrm{w}$ tabeli 1 , wartość produkcji w badanym przedsiębiorstwie jest uzależniona od wartości pozyskanych kontraktów, a więc od popytu na usługi firmy oraz dostępności i wydajności pracowników fizycznych. Nakłady pracy, obok dostępności kapitału na regulację zobowiązań są głównym elementem kształtowania się wartości produkcji, ale

\footnotetext{
${ }^{3}$ Zgodnych $\mathrm{z}$ wewnętrzną strukturą badanych procesów.
} 
też najważniejszym jej ograniczeniem. Nawet przy dużym wzroście popytu na usługi przedsiębiorstwa, to i tak jego moce są ograniczone do zasobów pracy, ich wydajności oraz dostępu do źródeł finansowania (regulowania zobowiązań).

Tabela 1. Oszacowanie równania produkcji (prod)

\begin{tabular}{|c|c|c|c|c|}
\hline Zmienna & Parametr & Błąd Stand. & Statystyka t & Prob. \\
\hline C & $-0,0301$ & 0,0134 & $-2,2381$ & 0,0283 \\
wp & 0,9475 & 0,0334 & 28,3443 & 0,0000 \\
wp(-1) & $-0,8966$ & 0,0508 & $-17,6164$ & 0,0000 \\
fiz & 0,8467 & 0,0413 & 20,5034 & 0,0000 \\
fiz(-1) & $-0,7931$ & 0,0591 & $-13,3967$ & 0,0000 \\
PRZET(-3) & 0,1006 & 0,0365 & 2,7565 & 0,0074 \\
prod(-1) & 0,9056 & 0,0436 & 20,7362 & 0,0000 \\
\hline R $^{2}$ & 0,9555 & \multicolumn{2}{|c|}{ Kryterium Akaike } & $-2,0109$ \\
Dopasowany R & 0,9519 & \multicolumn{2}{|c|}{ Kryterium Schwarza } & $-1,8025$ \\
Stat. Durbina-Watsona & 2,2714 & \multicolumn{2}{|c|}{ Statystyka F } & 261,6917 \\
\hline
\end{tabular}

prod - logarytm wartości produkcji w koszcie wytworzenia, fiz - logarytm średniej liczby zatrudnionych pracowników fizycznych w przeliczeniu na pełne etaty, wp - logarytm zespołowej wydajności pracy pracowników fizycznych liczony jako iloraz wartości produkcji wytworzonej $\mathrm{w}$ siłach własnych w stosunku do liczby zatrudnionych w przeliczeniu na pełne etaty, PRZET udział wygranych przetargów w ogólnej liczbie przygotowanych (w tym prywatnych i publicznych).

Źródło: opracowanie własne.

Ponadto analizowana funkcja opisująca produkcję wykazała wysoką rotację wśród kadry pracowników fizycznych. Wartości ocen parametrów przy zmiennych: zespołowej wydajności pracy i liczbie pracowników fizycznych dla okresu bieżącego i poprzedzającego mają przeciwne znaki.

W pracy Stryjewski, 2010 zaprezentowano skuteczność powyższego modelu w prognozowaniu wartości produkcji również w warunkach zmiany strukturalnej, jaką było załamanie produkcji budowlanej na przełomie 2008 i 2009 roku.

Reszty z modelu zaprezentowanego w tabeli 1 poddano testom na występowanie efektu ARCH. Tabela 2 przedstawia wartości testu Engle'a (Osińska, 2006, s. 83). Z tabeli 2 wynika, że należy odrzucić hipotezę zerową mówiącą o nieistotności parametrów w modelu ARCH dla reszt na poziomie istotności 5\%.

Tabela 2. Wyniki testu na występowanie efektu ARCH w modelu opisującym wartość produkcji.

\begin{tabular}{|c|c|c|}
\hline & Wartość & Prawdopodobieństwo \\
\hline Statystyka F & 2,8581 & 0,0071 \\
Obs $^{*} R^{2}$ & 21,0594 & 0,0124 \\
\hline
\end{tabular}

Źródło: opracowanie własne. 
Funkcja ACF dla reszt

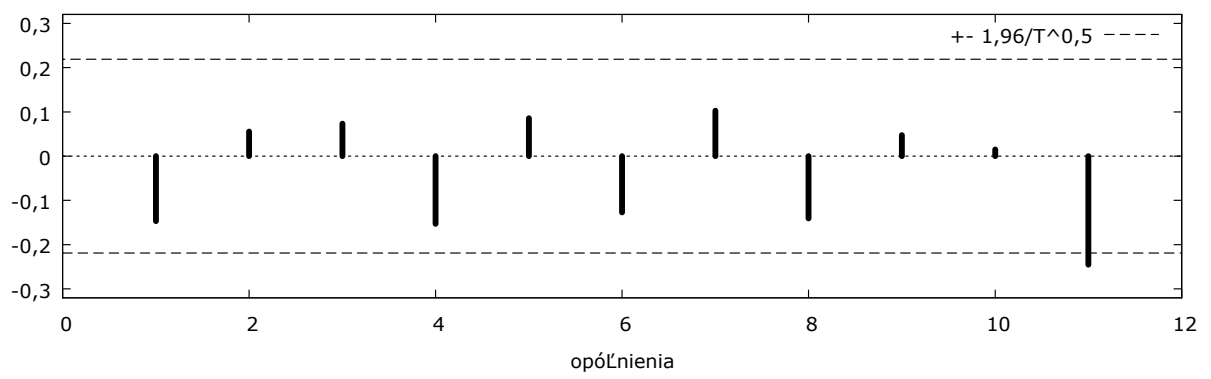

Funkcja PACF dla reszt

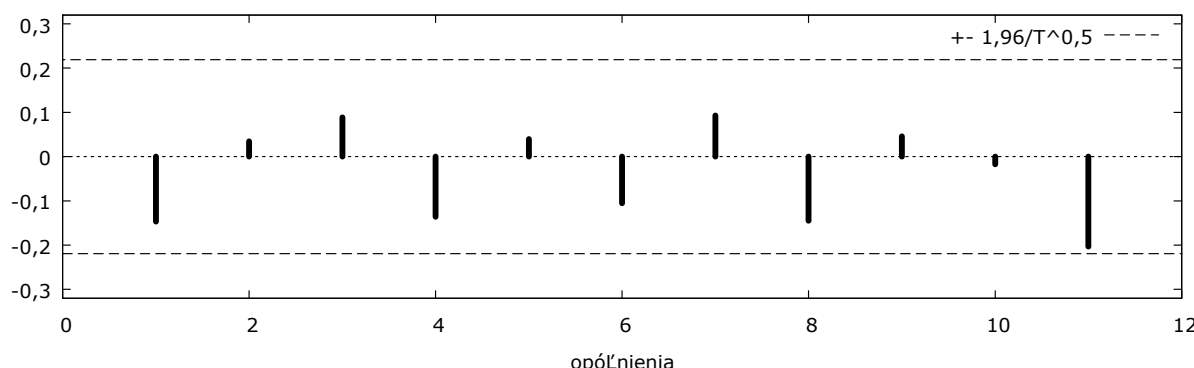

Rysunek 1. Funkcja autokorelacji oraz autokorelacji cząstkowej reszt dla równania produkcji (tabela 1)

Źródło: opracowanie własne.

Wyniki zamieszczone w tabeli 2 oznaczają, iż można dokonać badania zachowania się przedsiębiorstwa wobec ryzyka rynkowego. Modelowanie warunkowej wariancji wskazało, że na podstawie istotności parametrów rozważanych modeli oraz kryteriów informacyjnych, najlepszym modelem będzie ARCH(1).

W tabeli 3 zaprezentowano model opisujący wartość produkcji wraz z modelowaniem warunkowej wariancji reszt za pomocą modelu ARCH(1). Model ten oszacowano metodą największej wiarygodności łącznie dla wszystkich parametrów modelu (zarówno opisującego wartość produkcji w średniej, jak i w wariancji).

Analiza własności statystycznych modelu potwierdza jego dobre dopasowanie do danych rzeczywistych na poziomie ok. 95\%. Analiza funkcji autokorelacji cząstkowej (PACF) dla reszt wskazuje na brak autokorelacji (rysunek 2).

Ponadto analiza wyników testu na występowanie efektu ARCH w modelu przedstawionym w tabeli 3 wskazuje na brak podstaw do odrzucenia hipotezy zerowej o nieistotności parametrów w modelu ARCH dla reszt (por. tabela 4). Oznacza to, że włączenie do specyfikacji modelu opisującego kształtowanie się produkcji $\mathrm{w}$ przedsiębiorstwie budowlanym analizy ryzyka (poprzez równanie warunkowej wariancji) poprawia jego własności. Daje możliwość pełniejszej analizy poprzez włączenie brakującej zmiennej egzogenicznej. 
Tabela 3. Model GARCH-M opisujący kształtowanie się procesu produkcji (prod)

\begin{tabular}{|c|c|c|c|c|}
\hline Zmienna & Parametr & Błąd Stand. & Statystyka z & Prob. \\
\hline SQR(ht) & $-0,7935$ & 0,3821 & $-2,0763$ & 0,0379 \\
\hline C & 0,0362 & 0,0246 & 1,4715 & 0,1412 \\
\hline wp & 0,9404 & 0,0334 & 28,1369 & 0,0000 \\
\hline$w p(-1)$ & $-0,9001$ & 0,0513 & $-17,5503$ & 0,0000 \\
\hline fiz & 0,8474 & 0,0602 & 14,0737 & 0,0000 \\
\hline$f i z(-1)$ & $-0,7820$ & 0,0817 & $-9,5675$ & 0,0000 \\
\hline PRZET(-3) & 0,0708 & 0,0262 & 2,6992 & 0,0070 \\
\hline $\operatorname{prod}(-1)$ & 0,9069 & 0,0523 & 17,3228 & 0,0000 \\
\hline \multicolumn{5}{|c|}{ Variance Equation } \\
\hline$C$ & 0,0076 & 0,0013 & 5,8770 & 0,0000 \\
\hline $\mathrm{ARCH}(1)$ & 0,1465 & 0,0609 & 2,4076 & 0,0161 \\
\hline $\mathrm{R}^{2}$ & 0,9547 & \multirow{2}{*}{\multicolumn{2}{|c|}{ Kryterium Akaike }} & $-1,9931$ \\
\hline Dopasowany $\mathrm{R}^{2}$ & 0,9489 & & & $-1,6954$ \\
\hline Stat. Durbina-Watsona & 2,3269 & \multicolumn{2}{|c|}{$\begin{array}{l}\text { Kryterium Schwarza } \\
\text { Statystyka F }\end{array}$} & 164,1938 \\
\hline
\end{tabular}

$\mathrm{SQR}(\mathrm{ht})$ - pierwiastek procesu ARCH(1) dla reszt równania z tabeli 1.

Źródło: opracowanie własne.
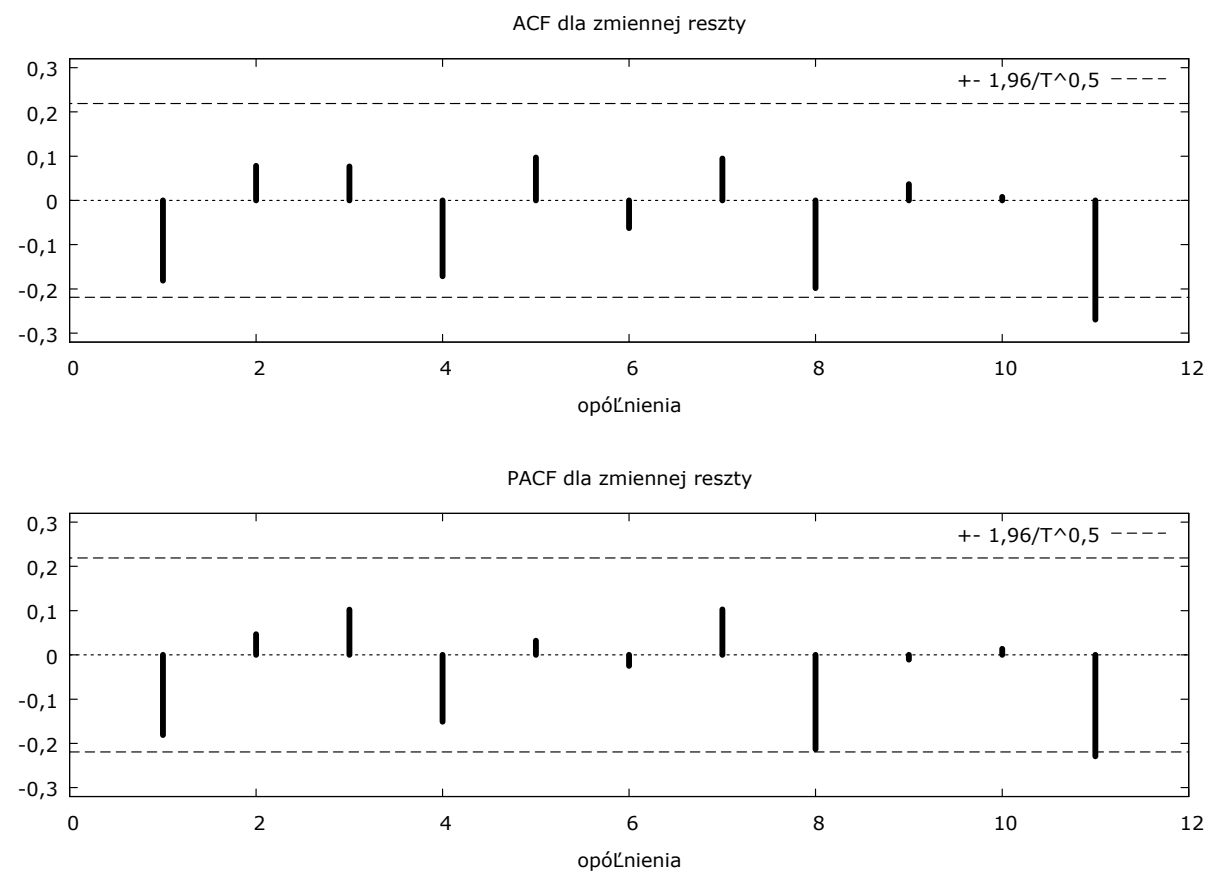

Rysunek 2. Funkcja autokorelacji oraz autokorelacji cząstkowej reszt dla równania produkcji - ARCH-M (tabela 3)

Źródło: opracowanie własne.

ACTA UNIVERSITATIS NICOLAI COPERNICI, EKONOMIA XLIII nr 2 (2012) 199-210 
Tabela 4. Wyniki testu na występowanie efektu ARCH w modelu GARCH-M

\begin{tabular}{|c|c|c|}
\hline & Wartość & Prawdopodobieństwo \\
\hline Statystyka F & 1,6565 & 0,1195 \\
Obs ${ }^{*}{ }^{2}$ & 13,9446 & 0,1243 \\
\hline
\end{tabular}

Źródło: opracowanie własne.

\section{PODSUMOWANIE}

Równanie przedstawione w tabeli 3 wskazało na istotność włączenia do równania kształtowania się produkcji w koszcie wytworzenia przedsiębiorstwa budowlanego procesu opisującego zmienne w czasie warunkowe odchylenie standardowe dla reszt $\mathrm{z}$ modelu opisanego w tabeli 1 . Włączenie do specyfikacji modelu GARCH-M tej zmiennej poprawiło własności reszt (patrz tabela 4), przy jednocześnie niezmienionych pozostałych miarach dopasowania modelu ( $\mathrm{R}^{2}$, autokorelacja itp.). Jak zaprezentowano na początku artykułu zmienna ta ma konkretną interpretację ekonomiczną niezależnie od znaku stojącego przy ocenie parametru. Interpretacja ta polega na określaniu zachowania przedsiębiorstwa wobec ryzyka rynkowego rozumianego jako wzrost wahań popytu na wyroby bądź usługi tego przedsiębiorstwa.

W analizowanym przypadku warunkowa zmienność w czasie interpretowana jako ryzyko rynkowe ujemnie wpływała na proces produkcji w przedsiębiorstwie budowlanym. Ocena parametru o wartości ok. $-0,79$ informuje iż, wzrost ryzyka o $100 \%$ powoduje spadek wartości produkcji w koszcie wytworzenia o ok. 79\%. Przedsiębiorstwo zatem zachowuje się defensywnie wobec ryzyka rynkowego, ograniczając produkcję wraz z jego wzrostem. Wzrost turbulencji rynkowych powoduje zmniejszenie skuteczności działań akwizycyjnych i koncentrację na kontraktach realizowanych, aby tam uzyskać odpowiednie do dalszego działania marże.

\section{LITERATURA}

Banaszkiewicz J., Bejm T., Bryl A., Górnik J., Kozera I., Leski J., Łapiński G., Wietrzyk A., Witalis M. (2003), Audyt wewnętrzny, Stowarzyszenie Księgowych w Polsce, Poznań.

Bollerslev T. (1986), Generalized Autoregressive Conditional Heteroskedasticity, „Journal of Econometrics", 31, 307-327.

Box G. E. P., Jenkins G. M. (1983), Analiza szeregów czasowych. Prognozowanie i sterowanie, PWN, Warszawa.

Drucker P. F. (2005), Praktyka zarzqdzania, MT Biznes, Warszawa.

Engle R (1982), Autoregressive Conditional Heteroscedasticity with Estimates of the Variance of United Kingdom Inflation, „Econometrica”, 50, 4, 987-1007.

Engle R., Lilien D., Robins R. (1987), Estimating Time Varying Risk Premia in the Term Structure: The Arch-M Model, „Econometrica”, 55, 2, 391-407.

Gruszczyński M., Podgórska M. (1996), Ekonometria, SGH, Warszawa.

Osińska M. (2006), Ekonometria finansowa, PWE Warszawa.

Pawłowski Z. (1976), Ekonometryczna analiza procesu produkcyjnego, PWN, Warszawa.

Porter M. (2006), Strategia konkurencji, MT Biznes, Warszawa.

Samuelson W.F., Marks S.G. (1998), Ekonomia menedzerska, PWE, Warszawa. 
Stryjewski T. (2010), Symulacyjna prognoza rozmiarów kryzysu w przedsiębiorstwie, „Przegląd Organizacji”, 3, 21-24.

Talaga L., Zieliński Z. (1986), Analiza spektralna $w$ modelowaniu ekonometrycznym, PWN, Warszawa.

Varian H.R. (2005), Mikroekonomia, PWN, Warszawa.

Żółtowska E. (1997), Funkcje produkcji, UŁ, Łódź

\section{THE ANALYSIS OF A COMPANY REACTION TO THE MARKET RISK}

A b s tra ct. Market risk is an inseparable phenomenon in running a business. Along with the risk growth, some of the companies react rationally by trying to reduce its influence on their activity (defensive action). The others can see a chance for market share growth as well as for profitability raising in turbulence moments (aggressive action). Then they can realize some additional bonus which results from the activities on difficult market. In this article there is an attempt to analyze the reaction of an enterprise to market risk changes by using a GARCH-M model.

$\mathrm{K}$ e y w o r d s: risk analysis, GARCH-M model, company. 